\title{
Effects of general anaesthesia on the intraocular pressure in man
}

\section{Comparison of tubocurarine and pancuronium in nitrous oxide and oxygen}

\author{
MOHAMED H. AL-ABRAK AND JOHN R. SAMUEL
}

From the Research Department of Anaesthetics, The Royal College of Surgeons of England, and St. Peter's Hospitals, London

The introduction of new anaesthetic drugs demands that their action should be compared with that of already established agents.

Pancuronium bromide was introduced into clinical anaesthetic practice by Baird and Reid ( 1967 ), and has since achieved widespread acceptance because it is reputed to have fewer cardiovascular side-effects than other non-depolarizing relaxants (Baird, I968; Sellick, I970; McDowall and Clarke, 1969; Stoelting, 1972; Feldman, 1973; Nightingale and Bush, I973).

Its effect on the intraocular pressure (IOP) has not previously been described except in a paper by Stanković, Driucić, and Prokić (I97I), who reported on its use in combination with halothane, and with nitrous oxide and halothane. However, since halothane has been shown to have marked effects on the IOP (Magora and Collins, I96r ; Mehta, I962; Wagenaar and Van der Wal, I964; Esposito, 1965), the present study was designed in such a way as to exclude other possible causes of change in the IOP by concurrently used agents and to compare the effects of pancuronium with those of tubocurarine under standard conditions.

The IOP was measured by a Perkins hand-held tonometer that can be used irrespective of the position of the patient (Perkins, I965). This instrument was chosen because it uses the principle of applanation which is more accurate than indentation tonometry with the Schiötz tonometer used in previous studies (Taylor, Mulcahy, and Nightingale, i968).

\section{Material and methods}

Ten patients undergoing urological surgery (all males aged $3^{\mathrm{I}}$ to $7^{\mathrm{I}} \mathrm{yrs}$ ) were investigated, five being studied for each drug. The nature of the study was explained to each patient and written consent obtained.

The methods were similar to those of a previous study by Beaugié and Samuel (1973). The respiratory and cardiovascular status was stabilized by the method of Samuel, Grange, and Hawkins (1968), substituting pancuronium for tubocurarine in the group in which pancuronium was studied.

The patients were not premedicated.

Either tubocurarine $0.5 \mathrm{mg} . / \mathrm{kg}$. body weight, or pancuronium bromide $0.1 \mathrm{mg} . / \mathrm{kg}$. were injected intravenously followed by thiopentone $5 \mathrm{mg}$. $/ \mathrm{kg}$. and pethidine $\mathrm{I} \cdot 0 \mathrm{mg} . / \mathrm{kg}$. The larynx was sprayed with lignocaine $100 \mathrm{mg}$. and a cuffed endotracheal tube introduced. Respiration was controlled with a Manley Ventilator set at constant pressure with a constant gas flow of $15 \mathrm{l} / \mathrm{min}$. (nitrous oxide 10 $1 . / \mathrm{min}$. and oxygen $5 \mathrm{l}$./min.) to minimize the effects of changes in intrathoracic pressure. The patients lay horizontal throughout the investigation. 
The end-tidal carbon dioxide concentration was maintained constant at 5 per cent. by adding carbon-dioxide to the inspired gases and the nitrous oxide flow rate was reduced by an equal volume to keep the inspired oxygen concentration and the minute volume constant.

The end-tidal carbon dioxide concentration $\left(\mathrm{FE} \mathrm{CO}_{2}\right)$ at the carina was measured by continuous sampling through a fine nylon catheter passed through the endotracheal tube mount. Samples were analysed by a Uras III infrared carbon dioxide analyser.

In all patients the IOP was measured before induction of anaesthesia, after instilling a local anaesthetic (lignocaine 0.5 per cent.) into the conjunctival sac. A second reading was taken Io min. after induction of anaesthesia and a third after a further $10 \mathrm{~min}$.

The pulse, blood pressure, and central venous pressure were measured as in the previous study.

\section{Results}

These are shown in Tables I and II. In the tubocurarine group there was a marked fall in IOP in every case, the mean percentage fall was statistically highly significant $(\mathrm{P}<0 \cdot 00 \mathrm{I})$. In the pancuronium group there was no significant change in IOP. Each patient acted as his own control.

Table I Effect of tubocurarine on intraocular pressure

\begin{tabular}{|c|c|c|c|c|c|c|c|c|c|c|c|c|}
\hline \multirow{3}{*}{$\begin{array}{l}\text { Patient } \\
\text { no. }\end{array}$} & \multicolumn{12}{|c|}{ Ohservation } \\
\hline & \multicolumn{4}{|c|}{$\begin{array}{l}\text { I Before induction of } \\
\text { general anaesthesia }\end{array}$} & \multicolumn{4}{|c|}{ II 10 min. after induction } & \multicolumn{4}{|c|}{ III 20 min. after induction } \\
\hline & IOP & BP & $\mathrm{HR}$ & CVP & IOP & BP & HR & CVP & IOP & BP & $\mathrm{HR}$ & CVP \\
\hline 1 & 16 & 180 & 86 & & \multirow{5}{*}{$\begin{array}{l}10 \\
(37 \cdot 5) \\
5 \\
(50) \\
10 \\
(41 \cdot 2) \\
9 \\
(47 \cdot 1) \\
8 \\
(55 \cdot 6)\end{array}$} & \multirow{5}{*}{$\begin{array}{l}165 \\
(8 \cdot 33) \\
115 \\
(4 \cdot 2) \\
110 \\
(15 \cdot 4) \\
110 \\
(15 \cdot 4) \\
110 \\
(15 \cdot 4)\end{array}$} & \multirow{5}{*}{$\begin{array}{l}72 \\
(16 \cdot 3) \\
64 \\
(5 \cdot 9) \\
72 \\
(2 \cdot 7) \\
72 \\
(2 \cdot 7) \\
88 \\
(-29 \cdot 4)\end{array}$} & 10 & $\begin{array}{l}8 \\
(50)\end{array}$ & \multirow{5}{*}{$\begin{array}{l}160 \\
(11 \cdot 11) \\
110 \\
(8 \cdot 33) \\
105 \\
(19 \cdot 23) \\
110 \\
(15 \cdot 4) \\
90 \\
(30 \cdot 8)\end{array}$} & \multirow{5}{*}{$\begin{array}{l}72 \\
(16 \cdot 3) \\
62 \\
(8 \cdot 8) \\
60 \\
(18 \cdot 9) \\
64 \\
(13 \cdot 5) \\
72 \\
(-5 \cdot 9)\end{array}$} & 10 \\
\hline 2 & 10 & 120 & 68 & & & & & 10 & $\begin{array}{l}4 \\
(60)\end{array}$ & & & 10 \\
\hline 3 & 17 & 130 & 74 & & & & & 10 & 8 & & & $10 \cdot 5$ \\
\hline \multirow[t]{2}{*}{4} & 17 & 130 & 74 & & & & & 9 & $\begin{array}{l}7 \\
(58 \cdot 8)\end{array}$ & & & 10 \\
\hline & 18 & 130 & 68 & & & & & 10 & $\begin{array}{l}6 \\
(66 \cdot 7)\end{array}$ & & & 10 \\
\hline \multicolumn{5}{|c|}{$\begin{array}{l}\text { Mean change (per cent.) } \\
\text { S.D. } \\
\text { P }\end{array}$} & $\begin{array}{c}46 \cdot 28 \\
7 \cdot 14 \\
<0.0005\end{array}$ & $\begin{array}{c}11.74 \\
5 \cdot 21 \\
<0.005\end{array}$ & $\begin{array}{l}-0 \cdot 36 \\
17 \cdot 17 \\
\text { N.S. }\end{array}$ & & $\begin{array}{c}57.68 \\
6.51 \\
<0.0005\end{array}$ & $\begin{array}{r}16 \cdot 97 \\
8 \cdot 77 \\
<0 \cdot 005\end{array}$ & $\begin{array}{r}10.32 \\
9.81 \\
<0.05\end{array}$ & \\
\hline
\end{tabular}

Figures in brackets denote percentage change from Observation I

$\mathrm{IOP}=$ intraocular pressure $(\mathrm{mm} . \mathrm{Hg}) \mathrm{BP}=$ systolic blood pressure $(\mathrm{mm} . \mathrm{Hg})$

$\mathrm{HR}=$ heart rate (beats per min.) $\quad \mathrm{CVP}=$ central venous pressure (mm.saline)

Table II Effect of pancuronium on intraocular pressure

\begin{tabular}{|c|c|c|c|c|c|c|c|c|c|c|c|c|}
\hline \multirow[t]{2}{*}{$\begin{array}{l}\text { Patient } \\
\text { no. }\end{array}$} & \multicolumn{4}{|c|}{$\begin{array}{l}\text { I Before induction of general } \\
\text { anaesthesia }\end{array}$} & \multicolumn{4}{|c|}{ II 10 min. after induction } & \multicolumn{4}{|c|}{ III 20 min. after induction } \\
\hline & $I O P$ & $B P$ & $H R$ & $C V P$ & $I O P$ & $B P$ & $H R$ & $C V P$ & $I O P$ & $B P$ & $H R$ & $C V P$ \\
\hline 1 & 15 & 130 & 100 & & \multirow{3}{*}{$\begin{array}{l}15 \\
(0) \\
14 \\
(0) \\
12 \\
(0) \\
19 \\
(0) \\
15 \\
(0)\end{array}$} & \multirow{3}{*}{$\begin{array}{l}130 \\
(0) \\
155 \\
(0) \\
120 \\
(0) \\
180 \\
(0) \\
110 \\
(0)\end{array}$} & \multirow{3}{*}{$\begin{array}{l}100 \\
(0) \\
74 \\
(0) \\
92 \\
(0) \\
68 \\
(0) \\
76 \\
(0)\end{array}$} & 11 & \multirow{3}{*}{$\begin{array}{l}15 \\
(0) \\
14 \\
(0) \\
12 \\
(0) \\
19 \\
(0) \\
15 \\
(0)\end{array}$} & \multirow{3}{*}{$\begin{array}{l}130 \\
(0) \\
150 \\
(3 \cdot 22) \\
115 \\
(4 \cdot 2) \\
175 \\
(2 \cdot 8) \\
110 \\
(0)\end{array}$} & \multirow{3}{*}{$\begin{array}{c}100 \\
(0) \\
74 \\
(0) \\
88 \\
(4 \cdot 4) \\
68 \\
(0) \\
82 \\
(-7 \cdot 9)\end{array}$} & 11 \\
\hline 4 & 19 & 180 & 68 & & & & & 8 & & & & 8 \\
\hline 5 & 15 & 110 & 76 & & & & & 6 & & & & 6 \\
\hline $\begin{array}{l}\text { Mean ch } \\
\text { S.D. } \\
\text { P }\end{array}$ & ge (pe & ent.) & & & $\begin{array}{l}0 \\
0 \\
\text { NS }\end{array}$ & $\begin{array}{l}\mathbf{0} \\
\mathbf{0} \\
\mathrm{NS}\end{array}$ & $\begin{array}{l}\mathbf{0} \\
\mathbf{0} \\
\mathrm{NS}\end{array}$ & & $\begin{array}{l}0 \\
0 \\
<\mathrm{NS}\end{array}$ & $\begin{array}{l}2 \cdot 04 \\
1 \cdot 93 \\
0 \cdot 05\end{array}$ & $\begin{array}{l}-0 \cdot 7 \\
4 \cdot 45 \\
-S\end{array}$ & \\
\hline
\end{tabular}

Figures in brackets denote percentage changes from Observation I

IOP = intraocular pressure (mm.Hg) BP = systolic blood pressure (mm. $\mathrm{mg}$ )

$\mathrm{HR}=$ heart rate (beats per min.) $\mathrm{CVP}=$ central venous pressure (mm.saline) 
The typical changes in one patient of each group are shown in Figs I and 2.

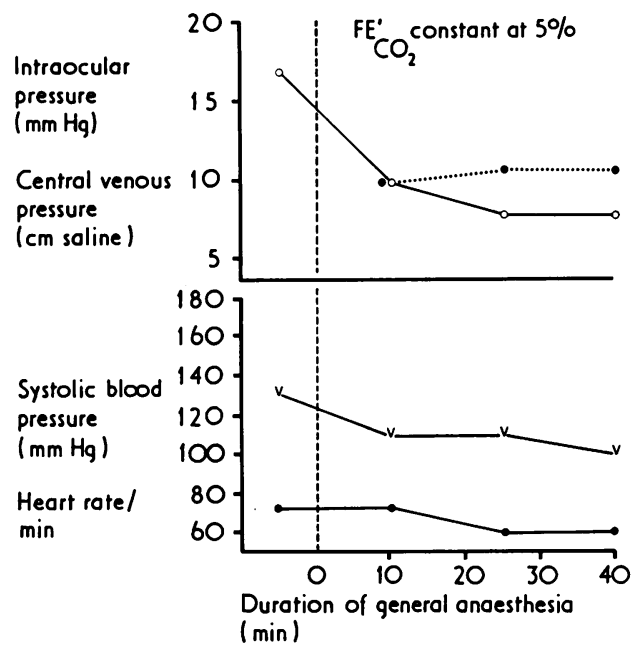

FIG. I Effect of $0.5 \mathrm{mg}$. $/ \mathrm{kg}$. curare on intraocular pressure

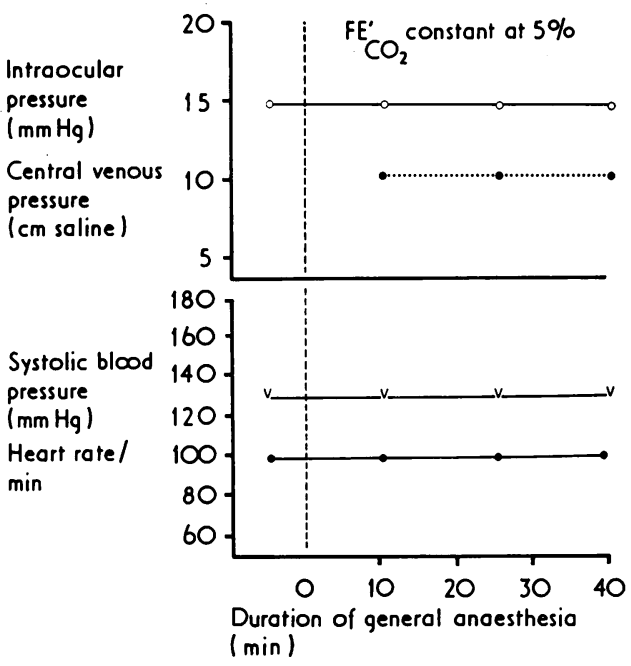

FIG. 2 Effect of $0.1 \mathrm{mg} . / \mathrm{kg}$. pancuronium on intraocular pressure

The change in blood pressure was highly significant statistically in the tubocurarine group but was not significant in the pancuronium group.

All the patients had normal IOP before induction of anaesthesia; the mean value was I $5.3 \mathrm{~mm} . \mathrm{Hg}$, which is within the normal range quoted by Leydhecker, Akiyama, and Neumann (1958).

\section{Discussion}

The rationale of the method used has already been discussed by Beaugié and Samuel (1973).

The present observation that the administration of tubocurarine lowers the IOP does not agree with that of Sadove and Unna (195I), who claimed no change in the IOP after tubocurarine, but it supports those of Colle, Duke-Elder, and Duke-Elder (193 I), Kirby (1950), Roche (1950), and Kornblueth, Aladjemoff, Magora, and Gobbay (1959), who reported varying degrees of fall in IOP after tubocurarine. The fall in IOP was attributed both to muscle paralysis and to the fall in blood pressure that accompanies the use of tubocurarine (Colle and others, I93I). These studies were conducted on animals, or humans, or both. Animal experiments are not necessarily applicable to man. Some species, like the cat, present greater differences, with constriction of the iris artery in response to many drugs (Macri, 1964; Grant, 1969). Even in the human studies no attempt was made to control other factors that affect the IOP, such as premedication (Leopold and Comroe, I948), general inhalational anaesthetics (Kornblueth and others, I959; Magora and Collins, I961), carbon-dioxide (Duncalf and Weitzner, 1963; Beaugié and Samuel, I973), and blood pressure (Adams and Barnett, I966).

Our results with pancuronium bromide do not agree with those of Stanković and others (1971), who reported a significant fall in IOP after the use of pancuronium in patients undergoing general surgical procedures. However, their results may not be valid because all the patients also received halothane which is known to cause a marked fall in IOP 
(Magora and Collins, I961; Mehta, I962; Wagenaar and Van der Wal, I964; Esposito, 1965). In addition, they failed to control the blood carbon dioxide tension which is another very potent factor in the maintenance of the IOP.

The planning of this study represents an attempt to keep unchanged as many as possible of these other factors affecting IOP. To achieve this, neither premedication nor depolarizing relaxants was given. Intrathoracic pressure was maintained unchanged by not altering the minute volume or inflation pressure. The inspired oxygen concentration was kept constant to avoid possible effects of changes in oxygen tension on the blood vessels of the eye, and the patient remained horizontal in the supine position to prevent hydrostatic changes which might alter the orbital venous pressure. The end-tidal carbon dioxide concentration was maintained constant at 5 per cent., as already described.

The blood pressure was observed not to alter significantly in the pancuronium group, which agrees with the findings of McDowall and Clarke (1969), Stoelting (1972), and Nightingale and Bush (1973), but there was a significant fall with tubocurarine, which supports the observation of Thomas (1957).

There was no change in central venous pressure in either group.

It is interesting to note that, although tubocurarine caused a marked fall in the IOP, pancuronium in a dose causing clinically equal paralysis produced no change. Kalff and Linzen (1969), studying alcuronium (Alloferin), found no fall in IOP after its administration except in doses large enough to produce a fall in systolic blood pressure. Goldsmith (1967) found that the IOP was entirely unaffected by gallamine. Thus the claim that the tone of the extraocular muscles plays a part in the control of the IOP should be reconsidered, and the fall in IOP caused by tubocurarine should be attributed to factors other than skeletal muscle paralysis, such as paralysis of orbital smooth muscle (Katz and Eakins, I969), autonomic ganglionic blockade, or hypotension.

Since many of the patients presented for intraocular surgery are past middle age with diminished cardiovascular compensation, there is a tendency to use pancuronium because it is claimed to have fewer depressant effects on the cardiovascular system. However, in these patients, because it is often desirable to lower the IOP, it may be preferable to use tubocurarine.

\section{Summary}

The effects of tubocurarine and pancuronium bromide on the intraocular pressure were investigated in ten patients under thiopentone nitrous oxide/oxygen anaesthesia. Pulmonary ventilation was controlled with maintenance of normal end-tidal carbon dioxide concentration. There was a fall in intraocular pressure in every patient receiving tubocurarine, but no significant change followed the use of pancuronium bromide.

We thank Mr. R. T. Turner-Warwick for permission to study his patients. We are indebted to Prof. J. P. Payne for his guidance in the preparation of the paper. We are grateful to Mr. I. Perry for computer analysis of the data and to Mrs. Sheila Askew for secretarial help. Our thanks are also due to the Department of Medical Illustration and Photography at the Institute of Urology, for the figures.

\section{References}

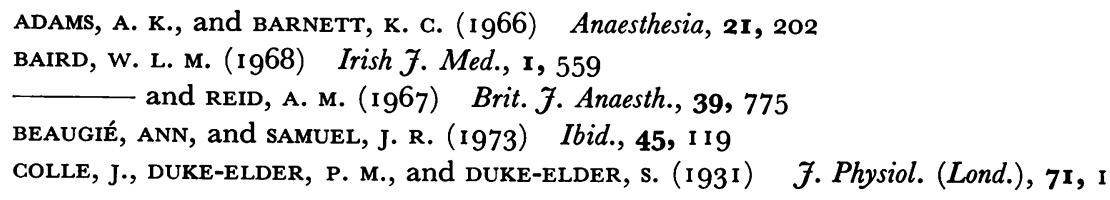


Duncalf, D., and Weitzner, s. W. (1963) Anesth. and Analg., 42, 232

ESPOSITO, A. C. (1965) Sth. med. F., 58, 992

feldman, s. A. (1973) "Muscle relaxants", in "Major Problems in Anaesthesia", vol. I, p. I73.

Saunders, Philadelphia

GOLDSMith, E. (1967) Anesth. and Analg., 46, 557

Grant, w. m. (1969) Ann. Rev. Pharmacol., 9, 85

KALFF, G., and LINZEN, M. (1969) Anaesthesist, 18, 2 I 7

Katz, R. L., and Eakins, K. E. (1969) Proc. roy. Soc. Med., 62, 1218

KIRBY, D. B. (1950) A.M.A. Arch. Ophthal., 43, 678

Kornblueth, w., Aladjemoff, L., Magora, F., and gobbay, A. (1959) Arch. Ophthal. (Chicago), 6i , 84 LEOPOLD, I. H., and COMROE, J. H. (1948) Ibid., 40, 285

leydhecker, W., akiyama, K., and neumann, H. G. (1958) Klin. Mbl. Augenheilk., 133, 662

MCDOWALl, S. A., and ClARKe, R. S. J. (1969) Anaesthesia, 24, 58I

MAGRI, F. J. (1964) Int. J. Neuropharmacol., 3, 205

MAGORA, F., and collins, V. J. (I96I) Arch. Ophthal. (Chicago), 66, 806

mehta, M. (1962) Brit. F. clin. Pract., 16, 339

Nightingale, D. A., and Bush, G. H. (1973) Brit. F. Anaesth., 45, 63

PERKINS, E. s. (1965) Brit. F. Ophthal., 49, 59I

ROCHE, J. R. (1950) Amer. F. Ophthal., 33, 91

SADOVE, M. S., and UNNA, K. R. (195I) Ibid., 34, 543

SAMUEL, J. R., GRANGE, R. A., and haWkins, T. D. (1968) Anaesthesia, 23, 543

SELLICK, B. A. (1970) "Clinical experience of a new muscle relaxant-pancuronium bromide", in

"Progress in Anaesthesiology: Proc. 4th World Congr. Anaesthesiologists, September, 1968".

Excerpta Medica, Amsterdam

STANKović, DRIUCIć, v., and PROKIĆ, D. (197I) Acta ophthal. iugosl., 9, 312

stoelting, R. K. (1972) Anesthesiology, 36, 612

taylor, T. H., MUlGahy, m., and nightingale, D. A. (I968) Brit. F. Anaesth., 40, I 13

THOMAS, E. T. (1957) Lancet, 2, 772

WAGENAAR, J. W., and VAN DER WAL, s. J. (1964) Ophthalmologica (Basel), 148, 184 